\title{
Leaves and roots of Typha latifolia L. and Iris pseudacorus L. as bioindicators of contamination of bottom sediments by heavy metals
}

\author{
Agnieszka Parzych ${ }^{{ }^{*}}$, Małgorzata Cymer ${ }^{2}$, Kamila Macheta ${ }^{1}$ \\ ${ }^{1}$ Environmental Chemistry Research Unit, Institute of Biology and Environmental Protection, Pomeranian Academy in Slupsk, Arciszew- \\ skiego 22b St., 76-200 Slupsk, Poland, e-mail: parzycha1@op.pl (*corresponding author) \\ ${ }^{2}$ Department of Land Reclamation and Environmental Development, University of Warmia and Mazury in Olsztyn, Plac Łódzki 2, 10-719 \\ Olsztyn, Poland
}

\begin{abstract}
The paper concerns the bioaccumulation of zinc, nickel, iron and manganese in leaves and roots of selected macrophytes from the Krzynia Reservoir (northern Poland). The research was conducted within the area of 10 stations situated in the littoral zone of the reservoir. Samples of surface waters, bottom sediments and plants were taken in summer. Heavy metal content was determined by the atomic absorption spectrometry method (ASA). The concentration of heavy metals in the waters of Krzynia Reservoir was low and noinfluence of anthropogenic factors was found. Concentration of heavy metals in the examined bottom sediments was low and remained within the limits of the geochemical background for $\mathrm{Zn}$ and Fe. In the case of $\mathrm{Ni}$ and $\mathrm{Mn}$ it sporadically exceeded the level of the geochemical background. The tested plants mainly accumulated heavy metals in roots, with the exception of nickel which appeared in larger quantities in leaves. The relationships among the content of the determined elements in the organs of macrophytes was identical for the tested species and could be arranged into the following sequences: $\mathrm{Mn}>\mathrm{Fe}>\mathrm{Ni}>\mathrm{Zn}$ in leaves and $\mathrm{Fe}>\mathrm{Mn}>\mathrm{Zn}>\mathrm{Ni}$ in roots. Statistically significant differences were found in the content of $\mathrm{Mn}$ in leaves and $\mathrm{Zn}$ and $\mathrm{Fe}$ in the roots of Typha latifolia $\mathrm{L}$. and Iris pseudacorus L. By accumulating substantial quantities of heavy metals in their organs, macrophytes constitute an effective protective barrier for the waters and bottom sediments.
\end{abstract}

Key words: lakes, macrophytes, microelements, bioconcentration factor, translocation factor

\section{Introduction}

Due to the environmental pollution of bottom sediments, plants and water it is possible to observe increased concentrations of various substances of anthropogenic origin, including heavy metals (Trojanowski et al. 2005; Parzych 2016; Parzych et al. 2016). To evaluate the quality of reservoirs and water courses, besides bottom sediments, littoral zone plants (macropytes) are used. They constitute one of the basic elements for the evaluation of the ecological status of the water. At present, the intense exploitation of catchments and the associated inflow of sewage have a substantial impact on the chemical composition of bottom sediments (Salati and Moore 2009). Heavy metals are biologically transformed and can persist in bottom sediments over a long period (Bettinetti et al. 2003; Liu et al. 2009). Bioavailable forms of metals bioaccumulate in the tissues of plants and animals, resulting in an increased risk of poisoning in subsequent links of the trophic chain (Klink et al. 2013; Parzych et al. 2016). Eco-tox- icological tests prove that plants uptake trace elements selectively from the surrounding environment. Such elements are used for the construction of their own tissues and participate in many metabolic conversions. Uptake of some mineral components from water and bottom sediments by plants is conditioned by a physiological demand for some of them and can also be an effect of the intoxication that results from environmental pollution (Parzych and Jonczak 2013, 2014; Parzych et al. 2016). The heavy metal content in plant tissues depends on the content and the bio-availability of such elements in the surrounding water environment as well as the plant species, the period of vegetation and the morphological differences (Parzych 2014). Plants react differently to increased concentrations of elements in the environment. Intake and bioaccumulation of necessary constituents is part of the natural cycle. The heavy metal content in aquatic plants can exceed their content in the surrounding water environment by many times (Baldantoni et al. 2004), such a wide range of variabil- 
ity is related to the biology and ecology of particular species. Some aquatic plants are used as bioindicators (Skorbiłowicz 2003; Rabajczyk and Jóźwiak 2009; Łojko et al. 2015, Parzych et al. 2015; Parzych 2016). Control of the chemical composition of littoral plants as well as bottom sediments in lakes is necessary, since it allows for specification of the existing and potential hazards that result from the toxic impact of heavy metals on the water environment.

The aim of this study was to compare the the accumulation properties of leaves and roots of Typha latifolia L. and Iris pseudacorus L. for zinc, nickel, iron and manganese. The study takes into account the effect of the water and bottom sediments on the tested macrophytes.

\section{Study area}

Krzynia is a retention reservoir situated within the area of the Dolina Landscape Park. It was established in 1925-1926 in conjunction with the construction of a water power station in the River Słupia. It covers an area of $74 \mathrm{ha}$, with a length of $3.5 \mathrm{~km}$, and its width is 0.4 $\mathrm{km}$. In the surrounding area of the reservoir there are beech forests, and in the direct neighbourhood one can find Caltha palustris L., Chrysosplenium alternifolium L., Galium palustre L., Cardamine amara L. and Myosoton aquaticum $\mathrm{L}$ while Phragmites australis (Cav.)Trin. ex Steud), Typha latifolia L., Glyceria maxima (Hartm.) Holmb. and Iris pseudacorus L. are present in the littoral zone of the lake, The average annual temperature of the air for the examined area is $7.6^{\circ} \mathrm{C}$, and annual precipitation is $700 \mathrm{~mm}$. The vegetation period lasts approximately 200 days a year. In summer, the reservoir is used for recreation and tourism.

\section{Methods}

Samples of water, bottom sediments and leaves and roots of Typha latifolia L. and Iris pseudacorus L. were collected from 10 stations located in the littoral zone of the Krzynia Reservoir (Northern Poland, $\left.54^{\circ} 20^{\prime} 47^{\prime \prime} \mathrm{N} 17^{\circ} 12^{\prime} 16^{\prime \prime} \mathrm{E}\right)$. Water $\mathrm{pH}$ was measured directly in the field using the potentiometer method (CPI 551, Elmetron, Poland), and electrical conductivity with the conductometric method (CC 315, Elmetron, Poland). Surface water samples were taken in polyethylene bottles of $1.5 \mathrm{dm}^{3}$ in volume. Bottom sediments were collected with an Eckman sampler from the depth of $0-15 \mathrm{~cm}$. Following transport to the laboratory, the samples were dried at a temperature of $65^{\circ} \mathrm{C}$ after which they were ground in a mortar and passed through a $1 \mathrm{~mm}$ sieve. The bottom sediments were examined for active acidity $\left(\mathrm{pH}, \mathrm{H}_{2} \mathrm{O}\right)$, exchange acidity $(\mathrm{pH}, \mathrm{KCl})$, and organic matter content using the heat loss method in a muffle furnace at a temperature of $550^{\circ} \mathrm{C}$. Macrophyte samples taken from within the area of each station were tested from several sprouts by preparation of mixed samples, separately made of leaves and separately of roots. After the transport to the laboratory the plant material was cleaned of mineral parts of the soil, flushed in distilled water, dried at a temperature of $65^{\circ} \mathrm{C}$ and then homogenized in a laboratory grinder (IKA A11, Germany).

All samples (water, bottom sediments, plants) were digested wet with concentrated nitric acid (65\%) and hydrogen peroxide (30\%). The concentration of $\mathrm{Zn}$, $\mathrm{Ni}, \mathrm{Fe}$ and $\mathrm{Mn}$ was determined by atomic absorption spectrometry (Aanalyst 300, Perkin Elmer, USA). The analyses were performed in an oxyacetylene flame. The wavelengths at which the various metals were detected are as follows $213.9 \mathrm{~nm} \mathrm{Zn}, 232.0 \mathrm{Ni}, 279.5 \mathrm{Mn}$ and $248.3 \mathrm{Fe}$. All the analyses were performed in three replicates. The tests were carried out following the original standards (Merck KGaA, 1 g per 1000 ml, Germany).

The analytical quality of the results were checked against the following reference materials: CRM 060 (aquatic plant), provided by the European Commission Institute for Reference Materials and Measurements. The results of the experimental measurements agreed with the recommended reference values of the material.

\section{Statistical analysis}

The distribution of the content of the analysed elements of water, of bottom sediments and leaves and roots of T. latifolia and I. pseudacorus was tested by the Shapiro-Wilk test. In order to identify the factors determining the heavy metal content in the bottom sediments, the factor analysis was applied (Principal Components Analysis, PCA). By application of the method of main components, 2 independent factors were separated explaining $67 \%$ of variance of the physicochemical composition of bottom sediments. The significance of the differences in the heavy metals in the leaves and roots in the content of T. latifolia and I. pseudacorus was verified by the non-parametric Mann Whitney $U$ test and compared to the natural content of $\mathrm{Zn}, \mathrm{Ni}, \mathrm{Fe}$ and Mn in plants (Tab. 4). The concentration of heavy metals in the sprouts of water plants, in the water and in the bottom sediments was used for calculation of bioconcentration factors (BCF). The bioconcentration factor was calculated as the ratio: concentration of elements in leaves/concentration of element in bottom sediments (or in water) (Salem et al. 2014). The relationship between the content of heavy metals in leaves and in roots of T. latifolia and I. pseudacorus was determined by translocation factors (TF). TF was calculated as the 
ratio: concentration of element in leaves/concentration of element in roots according Bose et al. (2008).

\section{Results and discussion}

Physicochemical properties of water and bottom sediments

Surface waters as well as bottom sediments of the Krzynia Reservoir were characterized by a neutral and slightly alkaline reaction (Table 1). The levels of electrolytic conductivity revealed low mineralization of the waters (EC; $0.26-0.27 \mathrm{mS} \mathrm{cm}^{-1}$ ). The organic matter content in the bottom sediments remained on average at the level of $45.8 \%$ and was substantially diversified among the stations. The heavy metal content in the surface waters of the Krzynia Reservoir was low and did not exceed the level of $0.647 \mathrm{mg} \mathrm{dm}^{-3}$ (Table 2), which indicated no anthropogenic pollution. Manganese was characterized by the highest variability of concentration within the research area $(67.6 \%)$. Slightly lower variability was was found in the nickel $(32.2 \%)$ and zinc (28.9\%). The natural origin of heavy metals in the case of water reservoirs depends on the geological structure and chemical composition of the rocks of the catchment (Czamara and Czamara 2008). Concentration of heavy metals in the examined bottom sediments was low and remained within the limits of the geochemical background for $\mathrm{Zn}$ and $\mathrm{Fe}$. In the case of $\mathrm{Ni}$ and $\mathrm{Mn}$ it sporadically exceeded the level of the geochemical background (Table 2). The highest diversity among the stations was found for nickel (45.4\%).

In order to identify factors that determine the participation of physicochemical components in bot-
Table 3. Factor loading obtained from the principal component analysis (PCA) method on the basis of the metal content in the bottom sediments of Krzynia Reservoir

\begin{tabular}{lcc}
\hline \multicolumn{1}{c}{ Parameter } & $\mathrm{F} 1$ & $\mathrm{~F} 2$ \\
\hline Organic matter & -0.77 & 0.12 \\
\hline $\mathrm{pH}(\mathrm{KCl})$ & -0.46 & -0.70 \\
\hline $\mathrm{pH}\left(\mathrm{H}_{2} \mathrm{O}\right)$ & -0.64 & -0.01 \\
\hline $\mathrm{Zn}$ & -0.77 & 0.38 \\
\hline $\mathrm{Ni}$ & 0.13 & 0.91 \\
\hline $\mathrm{Fe}$ & -0.72 & 0.12 \\
\hline $\mathrm{Mn}$ & -0.93 & -0.03 \\
\hline Eigen values & 3.19 & 1.49 \\
\hline \multirow{2}{*}{ Explained variance [\%] } & 0.46 & 0.21 \\
\cline { 2 - 3 } & \multicolumn{2}{c}{67} \\
\hline
\end{tabular}

Factor loadings higher than 0.7 are presented in boldface.

tom sediments, factor analysis was applied (PCA). In calculation, organic matter content, active acidity $\left(\mathrm{pH}, \mathrm{H}_{2} \mathrm{O}\right)$, exchange acidity $(\mathrm{pH}, \mathrm{KCl})$ and $\mathrm{Zn}, \mathrm{Ni}, \mathrm{Fe}$ and $\mathrm{Mn}$ content were taken into account (Table 3). By means of application of the method of main constituents, 2 independent factors were separated, explaining $67 \%$ of variability of the physicochemical composition of bottom sediments. For interpretation of data, only such factor loading values were used which exceeded 0.7 . Factor 1 explained $46 \%$ of variability and grouped organic matter, manganese, iron and zinc characterized by high, negative factor loads. The composition of 1 factor indicates that $\mathrm{Mn}, \mathrm{Fe}$ and $\mathrm{Zn}$ are strongly associated with decomposing organic matter which is a valuable source of metals (Jonczak et al. 2015). Factor 2 explained $27 \%$ of variability of the physicochemical

Table 1. Physicochemical properties of water and bottom sediments of Krzynia Reservoir

\begin{tabular}{lccccc}
\hline \multirow{2}{*}{ Value } & \multicolumn{2}{c}{ Water } & \multicolumn{3}{c}{ Bottom sediments } \\
\cline { 2 - 6 } & $\mathrm{pH}^{*}$ & $\mathrm{EC}\left[\mathrm{mS} \mathrm{cm}^{-1}\right]$ & $\mathrm{pH}^{*}\left(\mathrm{H}_{2} \mathrm{O}\right)$ & $\mathrm{pH}^{*}(\mathrm{KCl})$ & Organic matter [\%] \\
\hline Mean (median $\left.{ }^{*}\right) \pm \mathrm{SD}$ & $7.50 \pm 0.16$ & 0.26 & $6.90 \pm 0.19$ & $5.74 \pm 0.17$ & $45.8 \pm 6.4$ \\
\hline Minimum & 7.13 & 0.26 & 6.56 & 5.31 & 36.4 \\
\hline Maximum & 7.67 & 0.27 & 7.17 & 5.92 & 56.3 \\
\hline
\end{tabular}

Table 2. Heavy metal content in water $\left(\mathrm{mg} \mathrm{dm}^{-3}\right)$ and in bottom sediments $\left(\mathrm{mg} \mathrm{kg}^{-1}\right)$ of $\mathrm{Krzynia}$ Reservoir

\begin{tabular}{|c|c|c|c|c|c|}
\hline & Value & $\mathrm{Zn}$ & $\mathrm{Ni}$ & $\mathrm{Fe}$ & $\mathrm{Mn}$ \\
\hline \multirow{4}{*}{ 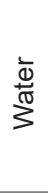 } & Mean \pm SD & 0.0320 .001 & 0.0230 .007 & $0.521 \pm 0.06$ & $0.060 \pm 0.04$ \\
\hline & Minimum & 0.020 & 0.014 & 0.444 & 0.008 \\
\hline & Maximum & 0.051 & 0.035 & 0.647 & 0.139 \\
\hline & $\mathrm{CV}[\%]$ & 28.9 & 32.2 & 12.1 & 67.6 \\
\hline \multirow{5}{*}{ 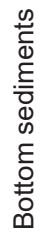 } & Mean \pm SD & $32.5 \pm 5.9$ & $11.4 \pm 5.2$ & $10361.8 \pm 2521.8$ & $599.3 \pm 83.3$ \\
\hline & Minimum & 26.7 & 4.8 & 7246.7 & 467.3 \\
\hline & Maximum & 47.2 & 21.0 & 14770.0 & 699.0 \\
\hline & CV [\%] & 18.3 & 45.4 & 24.3 & 13.9 \\
\hline & Geochemical background & $48.0^{1}$ & $5.0^{1}$ & $15000.0^{2}$ & $500.0^{1}$ \\
\hline
\end{tabular}

${ }^{1}$ Woitke et al. (2003); ${ }^{2}$ Bojakowska and Sokołowska (1998). 
composition of bottom sediments and was created by $\mathrm{Ni}$ and exchange acidity characterized by high, opposite factor loads.

\section{Heavy metals content in plants}

The heavy metal content in the organs of aquatic plants was substantially diversified. The highest levels of average zinc quantity were discovered in roots of T. latifolia $\left(61.7 \mathrm{mg} \mathrm{kg}^{-1}\right)$ and the lowest, in leaves of I. pseudacorus (22.6 mg kg $\mathrm{g}^{-1}$ ), (Table 4). Zn content in the organs of plants usually takes values from 10 to 70 $\mathrm{mg} / \mathrm{kg}$ (Kabata-Pendias and Pendias 1999) excluding the roots, which often exceed $70 \mathrm{mg} \mathrm{kg}^{-1}$ (Fig. 1, Table 4). Zinc is an essential micronutrient for plants (Deng et al. 2004). The sufficient concentration in leaves falls within the limit of $15-30 \mathrm{mg} \mathrm{kg}^{-1}$ which covers the physiological needs of most plants (Kabata-Pendias and Pendias 1999). $\mathrm{Zn}$ is a metal commonly introduced to surface waters along with surface flows. Similar relations in zinc distribution in aboveground and underground sprouts of various aquatic plants have been described in the works of Vardanyan and Ingole (2006), Parzych et al. (2015) and Parzych et al. (2016).

The average nickel content remained at the level of $29.0 \mathrm{mg} \mathrm{kg}^{-1}$ in leaves and $31.6 \mathrm{mg} \mathrm{kg}^{-1}$ in roots of T.latifolia and $90.8 \mathrm{mg} / \mathrm{kg}$ in leaves and $40.2 \mathrm{mg} \mathrm{kg}^{-1}$ in roots of I. pseudacorus (Table 4). At all stations higher $\mathrm{Ni}$ content in the organs of the examined plants was found. The natural nickel content in the leaves is usually 0.1-5.0 $\mathrm{mg} \mathrm{kg}^{-1}$ (Kabata-Pendias and Pendias 1999), but these levels can be higher since nickel easily undergoes bioaccumulation in water plants (Sarosiek and Wożakowska-Natkaniec 1993).

In the case of iron, very high levels of this element were found in the roots of T. latifolia $(6986.9 \mathrm{mg}$ $\mathrm{kg}^{-1}$ ) and I. pseudacorus (2375.2 $\mathrm{mg} \mathrm{kg}^{-1}$ ) (Fig. 1, Table $4)$. Iron concentration in leaves was low and remained at $145.0-198.6 \mathrm{mg} \mathrm{kg}^{-1}$. Iron is among the low mobility elements in a plant and is mostly gathered in the un- derground parts (Kabata-Pendias and Pendias 1999). A high content of iron in the roots of plants can indicate accumulative properties of that species in respect to Fe. At the same time, minor concentrations in the leaves (Fig. 1, Table 4) indicate the existence of a protective barrier, enabling the transfer of the iron compounds from the roots to leaves (Hozina et al. 2001).

The highest content of manganese was found in the roots of I. pseudacorus (774.0 $\mathrm{mg} \mathrm{kg}^{-1}$ ) (Fig. 1, Table 4). Mn concentration in leaves was lower at 759.1 $\mathrm{mg} \mathrm{kg}^{-1}$ (T.latifolia) and $382.8 \mathrm{mg} \mathrm{kg}^{-1}$ (I. pseudacorus). Plant demand for manganese is diverse, in most cases a sufficient level is $10-25 \mathrm{mg} \mathrm{kg}^{-1}$ (Kabata-Pendias and Pendias 1999). The increased Mn content in organs of aquatic plants indicates a positive influence of these macrophytes on purification of waters and bottom sediments from manganese compounds in relation to physiological demand and can be a genetic feature. Manganese concentrations are generally high in most plants as a consequence of its easily moving within plants to the above-ground plant organs (Salem et al. 2014).

The relationships regarding the content of the determined heavy metals in the organs of macrophytes was identical for the tested species and could be arranged into the following sequences: $\mathrm{Mn}>\mathrm{Fe}>\mathrm{Ni}>\mathrm{Zn}$ in leaves and $\mathrm{Fe}>\mathrm{Mn}>\mathrm{Zn}>\mathrm{Ni}$ in roots. The non-parametrical Mann-Whitney $U$ test revealed a series of statistically salient differences in the content of $\mathrm{Mn}$ in the leaves and $\mathrm{Zn}$ and $\mathrm{Fe}$ in the roots of Typha latifolia $\mathrm{L}$. and Iris pseudacorus L (Table 4). Through the accumulation of substantial quantities of heavy metals in their organs macrophytes created an effective protective barrier for the waters and bottom sediments.

\section{Bioaccumulation and translocation factors of heavy metals}

The examined water plants showed diversified accumulation properties in relation to zinc, nickel, iron and manganese present in water and bottom sediments. Levels of $\mathrm{BF}_{\mathrm{w}}$ indices ranged from 278.3 to 12 900. The

Table 4. The heavy metal content $\left(\mathrm{mg} \mathrm{kg}^{-1}\right) \pm \mathrm{SD}$ ( standard deviation) in leaves and roots of Typha latifolia and Iris pseudacorus and statistical differences in their concentration

\begin{tabular}{|c|c|c|c|c|c|c|c|c|}
\hline & & \multicolumn{2}{|c|}{ Typha latifolia } & \multicolumn{2}{|c|}{ Iris pseudacorus } & \multirow{2}{*}{$\begin{array}{c}\text { U Mann } \\
\text { Whitney test } \\
\text { p level }\end{array}$} & \multirow{2}{*}{$\begin{array}{l}\text { Natural } \\
\text { content } \\
\text { in plant }^{1}\end{array}$} & \multirow{2}{*}{$\begin{array}{c}\text { Toxity } \\
\text { content } \\
\text { in plant }{ }^{1}\end{array}$} \\
\hline & & mean & range & mean & range & & & \\
\hline \multirow[t]{2}{*}{$\mathrm{Zn}$} & Leaves & $28.6 \pm 5.7$ & $21.1-38.9$ & $22.6 \pm 7.2$ & $11.6-33.4$ & 0.180194 & \multirow{2}{*}{$10-70$} & \multirow{2}{*}{$>100$} \\
\hline & Roots & $61.7 \pm 14.3$ & $44.9-90.5$ & $40.3 \pm 11.2$ & $18.2-60.5$ & 0.004429 & & \\
\hline \multirow[t]{2}{*}{$\mathrm{Ni}$} & Leaves & $29.0 \pm 14.1$ & $14.5-60.6$ & $90.8 \pm 158.4$ & $11.2-533.3$ & 0.140237 & \multirow{2}{*}{$0.5-5$} & \multirow{2}{*}{$>10$} \\
\hline & Roots & $31.6 \pm 18.9$ & $10.5-68.9$ & $40.2 \pm 77.5$ & $4.6-258.9$ & 0.122911 & & \\
\hline \multirow[t]{2}{*}{$\mathrm{Fe}$} & Leaves & $145.0 \pm 30.7$ & $111.5-215.0$ & $198.6 \pm 121.8$ & $109.2-537.1$ & 0.069151 & \multirow{2}{*}{$5-375$} & \multirow{2}{*}{$\begin{array}{c}\text { toxic not } \\
\text { know }\end{array}$} \\
\hline & Roots & $6986.9 \pm 2553.1$ & $3198.0-11913.0$ & $2375.2 \pm 1721.7$ & $200.2-4793.7$ & 0.000300 & & \\
\hline \multirow[t]{2}{*}{$\mathrm{Mn}$} & Leaves & $759.1 \pm 206.7$ & $470.6-1241.7$ & $382.8 \pm 191.4$ & $106.8-789.5$ & 0.004429 & \multirow{2}{*}{$10-25$} & \multirow{2}{*}{$>500$} \\
\hline & Roots & $770.7 \pm 230.9$ & $348.9-1118.3$ & $774.0 \pm 396.8$ & $346.1-1681.7$ & 0.871760 & & \\
\hline
\end{tabular}

${ }^{1}$ Kabata-Pendias and Pendias (1999). 

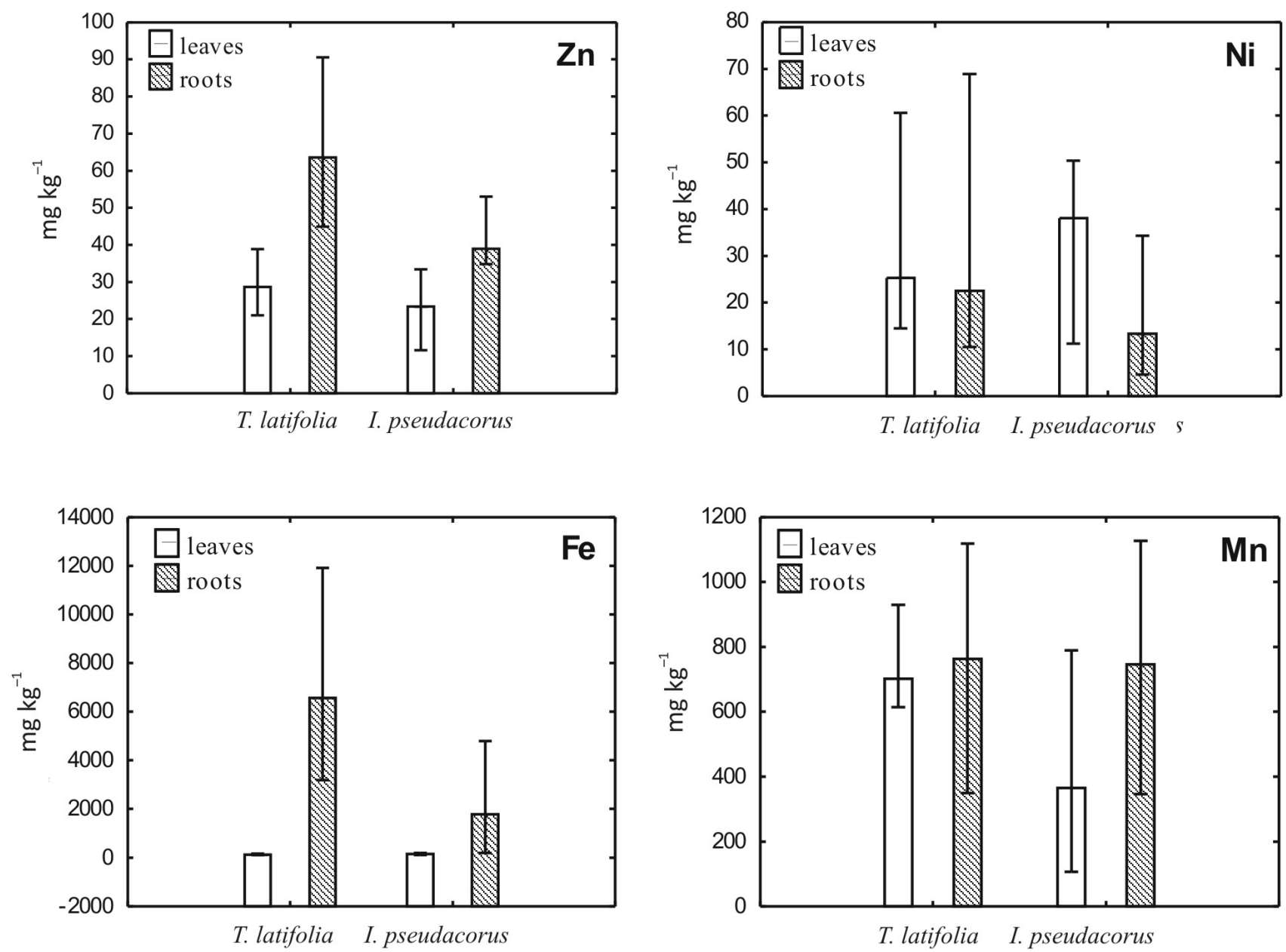

Fig. 1. Median, minimum and maximum content of heavy metals in the organs of aquatic plants in Krzynia Reservoir

highest bioaccumulation was found in the case of manganese and iron and slightly lower with respect to zinc and nickel. The reaction of the examined water was a positive factor for the accumulation of $\mathrm{Mn}$ and $\mathrm{Fe}(\mathrm{Ta}-$ ble 1). The main factor influencing the availability of heavy metals for the examined plants is the reaction of water and bottom sediments. Solubility of metals is low to neutral and alkaline reactions increase along with a lowering of the value of $\mathrm{pH}$. Increased mobility of $\mathrm{Zn}$ and $\mathrm{Mn}$ is most effective with $\mathrm{pH}=6, \mathrm{Ni}$ at $\mathrm{pH}$ $=5.5$, while for $\mathrm{Fe}$ at $\mathrm{pH}=4$. Manganese, however, is also characterized by increased solubility in an alkaline environment (Alloway 1995; Smal and Salomons 1995). Much higher quantities of heavy metals were accumulated in the roots than in the leaves of the examined species with the exception of I. pseudacorus, in which case larger quantities of $\mathrm{Ni}$ were found in leaves. The highest levels of $\mathrm{BF}_{\mathrm{bs}}$ were found for $\mathrm{Ni}$ (2.54-7.96), slightly lower for $\mathrm{Zn}(0.69-1.89)$ and $\mathrm{Mn}(0.64-1.29)$. Bioaccumulation factors for Fe had the lowest values (0.01-0.67), both in the case of leaves and roots of $T$. latifolia and I. pseudacorus (Table 5). The high levels of $\mathrm{BF}_{\mathrm{bs}}$ for nickel confirm the high mobility and ease of accumulation of this element in the plant tissues. The

Table 5. Bioaccumulation factors (BF) of heavy metals in plants from Krzynia Reservoir

\begin{tabular}{|c|c|c|c|c|c|c|c|c|c|}
\hline \multirow{2}{*}{\multicolumn{2}{|c|}{ Species }} & \multicolumn{2}{|c|}{$\mathrm{Zn}$} & \multicolumn{2}{|c|}{$\mathrm{Ni}$} & \multicolumn{2}{|c|}{$\mathrm{Fe}$} & \multicolumn{2}{|c|}{$\mathrm{Mn}$} \\
\hline & & \multirow{2}{*}{$\begin{array}{l}\mathrm{BF}_{\mathrm{bs}} \\
0.88\end{array}$} & \multirow{2}{*}{$\begin{array}{r}\mathrm{BF}_{\mathrm{w}} \\
893.7\end{array}$} & \multirow{2}{*}{$\begin{array}{l}\mathrm{BF}_{\text {bs }} \\
2.54\end{array}$} & \multirow{2}{*}{$\frac{\mathrm{BF}_{\mathrm{w}}}{537.0}$} & \multirow{2}{*}{$\begin{array}{l}\mathrm{BF}_{\mathrm{bs}} \\
0.01\end{array}$} & \multirow{2}{*}{$\begin{array}{r}\mathrm{BF}_{\mathrm{w}} \\
278.3\end{array}$} & \multirow{2}{*}{$\begin{array}{l}\mathrm{BF}_{\text {bs }} \\
1.27\end{array}$} & \multirow{2}{*}{$\begin{array}{l}\mathrm{BF}_{\mathrm{w}} \\
12651.7\end{array}$} \\
\hline Typha latifolia & Leaves & & & & & & & & \\
\hline & Roots & 1.89 & 1228.1 & 2.77 & 585.2 & 0.67 & 13410.5 & 1.29 & 12845.0 \\
\hline \multirow[t]{2}{*}{ Iris pseudacorus } & Leaves & 0.69 & 706.2 & 7.96 & 1681.5 & 0.02 & 381.2 & 0.64 & 6380.0 \\
\hline & Roots & 1.89 & 1259.4 & 3.53 & 744.4 & 0.23 & 4558.9 & 1.29 & 12900.0 \\
\hline
\end{tabular}

Note: $\mathrm{BF}_{\mathrm{bs}}-$ calculated on the basis of heavy metals concentration in bottom sediments, $\mathrm{BF}_{\mathrm{w}}-$ calculated on the basis of heavy metals concentration in water. 
Table 6. Translocation factor (TF) of heavy metals in organs (Leaves/ Roots) of Typha latifolia and Iris pseudacorus from Krzynia Reservoir

\begin{tabular}{lcccc}
\hline \multicolumn{1}{c}{ Species } & $\mathrm{Zn}$ & $\mathrm{Ni}$ & $\mathrm{Fe}$ & $\mathrm{Mn}$ \\
\hline Typha latifolia & 0.46 & 0.91 & 0.02 & 0.98 \\
\hline Iris pseudacorus & 0.56 & 2.26 & 0.08 & 0.49 \\
\hline
\end{tabular}

strong cumulative property of some macrophytes in reference to nickel has been confirmed in the research of Salt and Kramer (2000), Mays and Edwards (2001), Parzych (2014) and Parzych et al. (2016). The values of $\mathrm{BF}_{\mathrm{w}}$ and $\mathrm{BF}_{\mathrm{bs}}$ confirm the very close interactions between water, bottom sediments and plants.

By means of translocation factors (TF) mobility of zinc, nickel, iron and manganese in relation leavesroots was represented. From among the examined heavy metals, nickel showed the highest mobility in the organs of $I$. pseudacorus $(\mathrm{TF}=2.26)$. The levels of translocation factors in the case of the remaining metals were $\mathrm{TF}<1.0$ (Table 6). Nickel is easily accumulated by plants and transported to their aboveground parts, and when in excess, it is accumulated in the roots (Kabata-Pendias and Pendias 1999).

\section{Conclusion}

The analysis of the physicochemical and chemical analysis of the waters, bottom sediments and organs of macrophytes revealed substantial variations between the stations and species. The concentration of heavy metals in the waters and bottom sediments of the Krzynia Reservoir was low and excluded any impact of anthropogenic factors. Two independent main factors, determined by PCA, explain $67 \%$ of the total variability of the physicochemical composition of the bottom sediments. Factor 1 explained $46 \%$ of variants and its composition confirmed the strong relationship between $\mathrm{Mn}, \mathrm{Fe}$ and $\mathrm{Zn}$ with organic matter. Factor 2 explained $27 \%$ of variability of the physical and chemical composition of the examined bottom sediments and was made up of $\mathrm{Ni}$ and $\mathrm{pH}(\mathrm{KCl})$, thus confirming the increasing mobility of nickel along with acidification of the environment. The tested plants mainly accumulated heavy metals in roots, with the exception of nickel which appeared in larger quantities in the leaves. The relationships respecting the content of the determined elements in the macrophyte organs was identical for the tested species and could be arranged into the following sequences: $\mathrm{Mn}>\mathrm{Fe}>\mathrm{Ni}>\mathrm{Zn}$ in leaves and $\mathrm{Fe}>\mathrm{Mn}>\mathrm{Zn}>\mathrm{Ni}$ in roots. Statistically significant differences were found in the content of $\mathrm{Mn}$ in the leaves and $\mathrm{Zn}$ and $\mathrm{Fe}$ in the roots of Typha latifolia and Iris pseudacorus By accumulating substantial quantities of heavy metals in their organs, macrophytes constitute an effective protective barrier for the waters and bottom sediments.

\section{References}

Alloway B.J., 1995, Soil processes and the behavior of metals, [in:] Alloway B.J. (ed.), Heavy metals in soils, Blackie, Glasgow 7-28.

Baldantoni D., Alfani A., Di Tommasi P., Bartoli G., Virzo de Santo A., 2004, Assessment of macro and microelement accumulation capability of two aquatic plants, Environ. Pollut. 130: 149-156.

Bettinetti R., Giarei C., Provini A., 2003, A chemical analysis and sediment toxicity bioassays to assess the contamination of the River Lambro (Northern Italy), Arch. Environ. Contamin. Toxicol. 45: 2-80.

Bojakowska I., Sokołowska G., 1998, Geochemiczne klasy czystości osadów wodnych (Geochemical classes of water sediments quality), Prz. Geol. 46(1): 49-54 (in Polish).

Bose S., Chandrayan S., Rai V., Bhattacharyya A.K., Ramanathan A.L. 2008, Translocation of metals in pea plants grown on various amendment of electroplating industrial sludge, Bioresour. Technol. 99: 4467-4475.

Czamara A., Czamara W., 2008, Metale ciężkie w systemie ekologicznym zbiornika Mściwojów (Heavy metals in ecological system of Mściwojów Reservoir), Infractructure and Ecology of Rural Areas 9: 283-296 (in Polish, English summary).

Deng H., Ye Z.H., Wong M.H., 2004, Accumulation of lead, zinc, copper and cadmium by 12 wetland plant species thriving in metal-contaminated sites in China, Environ. Pollut. 132: 29-40.

Hozhina E.I., Khramov A.A., Gerasimov P.A., Kumarkov A.A., 2001, Uptake of heavy metals, arsenic, and antimony by aquatic plants in the vicinity of ore mining and processing industries, J. Geochem. Explor. 74: 153-164.

Jonczak J., Parzych A., Sobisz Z., 2015, Decomposition of four leaf litters in headwater riparian forest, Baltic Forestry 21(1): 133-143.

Kabata-Pendias A., Pendias H., 1999, Biogeochemia pierwiastków śladowych (Biogeochemistry of trace elements), Wydaw. Nauk. PWN, Warszawa, 400 pp. (in Polish).

Klink A., Wisłocka M., Musiał M., Krawczyk J., 2013, Macroand trace-elements accumulation in Typha angustifolia $\mathrm{L}$. and Typha latifolia L. organs and their use in bioindication, Pol. J. Environ. Stud. 22(1): 183-190.

Liu J., Li Y., Zhang B., Cao J., Cao Z., Domagalski J., 2009, Ecological risk of heavy metals in sediments of the Luan River source water, Ecotoxicology 18: 748-758.

Łojko R., Polechońska L., Klink A., Kosiba P., 2015, Trace metal concentrations and their transfer from sediment to leaves of four common aquatic macrophytes, Environ. Sci. Pollut. Res. 22(19) 15123-15131.

Mays P.A., Edwards G.S., 2001, Comparison of heavy metal accumulation in a natural wetland and constructed wet- 
lands receiving acid mine drainage, Ecol. Eng. 16: 487500.

Parzych A., 2014, Heavy metals accumulation in moss Pleurozium schreberi (Brid.) Mitt. and Hylocomium splendens (Hedw.) B.S.G. in the Słowiński National Park, J. Elem. 19(2): 471-482.

Parzych A., 2016, The chemical elements accumulation by organs of Sparganium erectum L. and their potential use in phytoremediation process, J. Ecol. Eng. 17(1): 89-100.

Parzych A., Jonczak J., 2013, Content of heavy metals in needles of Scots pine (Pinus sylvestris L.) in selected of pine forest in the Słowiński National Park, Arch. Environ. Prot. 1(39): 41-51.

Parzych A., Jonczak J., 2014, Pine needles (Pinus sylvestris L.) as bioindicators in the assessment of urban environmental contamination with heavy metals, J. Ecol. Eng.15(3): 29-38.

Parzych A., Cymer M., Jonczak J., Szymczyk S., 2015, The ability of leaves and rhizomes of aquatic plants to accumulate macro- and micronutrients, J. Ecol. Eng., 16, 3: 198-205.

Parzych A., Sobisz Z., Cymer M. 2016, Preliminary research of heavy metals content by aquatic macrophytes taken from surface water (northern Poland), Desalin. Water Treat. 57(3): 1453-1463.

Rabajczyk A., Jóźwiak M.A., 2009, Możliwości wykorzystania makrofitów jako bioindykatorów metali ciężkich zdeponowanych w osadach dennych (The possibilities of using macrophytes as bioindicators of heavy metals occurring in sediments), Monit. Środ. Przyr. 9: 19-26 (in Polish).

Salati S., Moore F., 2009, Assessment of heavy metal concentration in the Khoshk River water and sediment, Shiraz, Southwest Iran, Environ. Monit. Assess. 164: 677-689.
Salem Z.B., Laffray X., Ashoour A., Ayadi H., Aleya L. 2014, Metal accumulation and distribution in the organ of reeds and cattails in a constructed treatment wetland (Etueffont, France), Ecol. Eng. 64: 1-17.

Salt D.E., Kramer U., 2000, Mechanisms of metal hyperaccumulation in plants, [in:] Raskin I., Ensley B.D. (eds), Phytoremediation of toxic metals: Using plants to clean up the environment, Wiley, New York: 231-246.

Sarosiek J., Wożakowska-Natkaniec H., 1993, Chrom i nikiel $\mathrm{w}$ roślinach $\mathrm{z}$ rodziny Lemnaceae $\mathrm{i} \mathrm{w}$ ich środowisku (Chromium and nickel in plants of the Family Lemnaceae and in their environment), [in:] Kabata-Pendias A. (ed.) Chrom nikiel i glin - problemy ekologiczne i metodyczne (Chromium, nickel and aluminum - ecological problems and methodical), Zesz. Nauk. Kom. "Człowiek i środowisko" PAN 5: 49-54 (in Polish, English summary).

Skorbiłowicz E., 2003, Heavy metal content in bottom deposits and water plants in the Ełk River on urbanized area, Ecol. Chem. Eng. 10(9): 937-945.

Smal H., Salomons W., 1995, Acidification and its long-term impact on metal mobility, [in:] Salomons W., Stigliani W. (eds), Biogeodynamics of pollutants in soils and sediments, Springer-Verlag, Berlin: 193-212.

Trojanowski P., Trojanowski J., Parzych A., 2005, Copper, zinc, manganese, lead and cadmium in Plants of Gardno Lake, Arch. Environ. Prot. 31(4): 45-58.

Vardanyan L.G., Ingole B.S., 2006, Studies on heavy metal accumulation in aquatic macrophytes from Sevan (Armenia) and Carambolim (India) lake system, Environ. Int. 32: 208-218.

Woitke P., Wellmitz J., Helm D., Kube P., Lepom P., Litheraty P. 2003. Analysis and assessment of heavy metal pollution in suspended solids and sediments of the river Danube, Chemosphere 51: 633-642. 